\title{
Reproductive features of the swimming crab Callinectes danae (Crustacea, Portunoidea) on the subtropical coast of Brazil: a sampling outside the estuary
}

\author{
Andrade, LS. ${ }^{a, b *}$, Antunes, M. ${ }^{a, c}$, Lima, PA. ${ }^{a, c}$, Furlan, M. ${ }^{a, c}$, Frameschi, IF ${ }^{a, c}$ and Fransozo, A. ${ }^{a, c}$

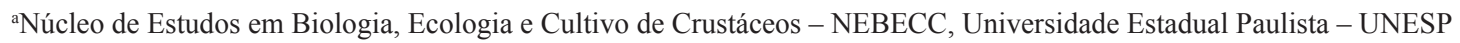 \\ Distrito de Rubião Junior, s/n, Campus de Botucatu, CEP 18618-970, Botucatu, SP, Brazil \\ bUniversidade Federal do Triângulo Mineiro - UFTM, Rua Rio Paranaíba, 1229, Campus Iturama, \\ CEP 38280-000, Iturama, MG, Brazil \\ 'Departamento de Zoologia, Instituto de Biociências, Universidade Estadual Paulista - UNESP, \\ Distrito de Rubião Junior, s/n, Campus de Botucatu, CEP 18618-000, Botucatu, SP, Brazil \\ *e-mail: andradels.nebecc@gmail.com
}

Received: November 13, 2013 - Accepted: May 23, 2014 - Distributed: August 31, 2015

(With 5 figures)

\begin{abstract}
The life cycle of the crab Callinectes danae is estuarine-dependent, and studies on aspects of their biology should also cover marine areas. The present study investigated the sexual maturity, as well as habitat preference by adults in different gonadal stages, and the crabs' reproductive periodicity outside the estuary. Three bays on the subtropical southeastern coast of Brazil were sampled monthly for two years. For each bay, six transects were established, four of them parallel to the beach line $(5,10,15$ and $20 \mathrm{~m}$ depth), as well as one transect in an exposed area, and another sheltered from the action of waves. The results showed that the pattern of spatio-temporal distribution of adults $C$. danae was similar in three bays, although the highest abundance was found in Ubatumirim. Females with developed gonads/ovigerous females were found in greater abundance than females with rudimentary/developing gonads, mainly in deeper transects. Although the areas sampled have different environmental characteristics, the reproductive pattern of the species did not change, showing continuous reproduction throughout, with more abundance of reproductive females on spring and summer. Males reached maturity at larger sizes than females in all three bays.
\end{abstract}

Keywords: blue crab, change in habitat use, reproductive activity, sexual maturity.

\section{Características reprodutivas do siri Callinectes danae (Crustacea, Portunoidea) na região subtropical da costa do Brasil: uma amostragem fora do estuário}

\begin{abstract}
Resumo
O siri Callinectes danae é estuarino dependente em seu ciclo de vida, sendo que os estudos que levantam informações sobre os aspectos da sua biologia devem também abranger regiões marinhas. Assim, o presente estudo teve como objetivo investigar a maturidade sexual, bem como a preferência ocupacional por adultos em diferentes estágios gonadais e sua periodicidade reprodutiva fora da região estuarina. Para tanto, três enseadas da porção subtropical do litoral sudeste brasileiro foram amostradas mensalmente, durante dois anos. Para cada enseada, seis transectos foram estabelecidos, quatro deles paralelos à linha de praia $(5,10,15$ e $20 \mathrm{~m}$ de profundidade), um transecto exposto e outro abrigado à ação de ondas. Os resultados mostraram que o padrão de distribuição espaço-temporal de adultos de $C$. danae foi similar nas três enseadas, embora uma maior abundância tenha sido encontrada em Ubatumirim. Fêmeas ovígeras e com gônadas desenvolvidas foram encontradas em maior abundância que fêmeas com gônadas rudimentares e em desenvolvimento, principalmente nos transectos mais profundos. Apesar das regiões amostradas possuírem características ambientais diferenciadas, o padrão reprodutivo da espécie não sofreu alterações, apresentando reprodução contínua, com maior abundância de fêmeas reprodutivas na primavera e verão. Machos atingiram maturidade em tamanhos maiores que as fêmeas nas três enseadas.
\end{abstract}

Palavras-chave: siri azul, alterações na ocupação do hábitat, atividade reprodutiva, maturidade sexual. 


\section{Introduction}

Knowledge of the reproductive biology of a species should be seen as fundamental information for understanding its life cycle. This knowledge is necessary for the administration of a controlled and sustainable fishery, and the preservation of species that have no commercial interest but are directly involved in the food chain (Almeida et al., 2011). Understanding the reproductive patterns can encourage exploitation of this source of food in a sustainable manner, generating income for the population dependent on fisheries and conserving marine communities.

The reproductive periodicity of many species of brachyuran crabs has been studied using the monthly proportion of ovigerous females and non-ovigerous females with developed gonads during the year (see Costa and Negreiros-Fransozo, 1998; Andrade et al., 2014a). Nevertheless, reproductive females may have different habitat preferences than the rest of the population, and may occur in other locations and not be present in samples from the area chosen for collection. Studies of the reproductive periodicity of Callinectes danae Smith, 1869 on the Brazilian coast include those of Costa and Negreiros-Fransozo (1998), which did not report the sampling depths, and Branco and Masunari (2000), Keunecke et al. (2012), Sant'Anna et al. (2012) and Marochi et al. (2013), which covered only estuarine areas.

As important as collecting information about the reproductive period, estimating the size at which a species reaches sexual maturity is also important for understanding its biology and consequent conservation. To estimate this value, the total percentage of adults per size class should be used. However, some studies have considered individuals with rudimentary gonads as immature (see Araújo et al., 2012), although this gonadal stage is only indicative of depleted gonads (Keunecke et al., 2009). If these individuals are classed as immature, the size at which the species reaches maturity may be overestimated, which would undermine the protection of the stock population. Likewise, using the size of the smallest ovigerous female as a parameter of maturity may also be questionable, since this technique may underestimate the size at maturity of males due to differential growth between the genders (see Costa and Negreiros-Fransozo, 1998). Accurate knowledge of the reproductive biology of estuary-dependent crabs is important, not only for the preservation of the species, but also, indirectly, for their environment, because they aid in structuring the local community. According to Diegues (1999), the estuarine ecosystems of southeastern Brazil are in a critically degraded condition, which indicates that information on species should be acquired over the entire area of occupancy. Given that most studies on $C$. danae are performed in estuaries, this study sampled these individuals in the sublittoral zone, in order to investigate the differential occupancy by adults at different gonadal stages, the reproductive periodicity, and the sexual maturity of males and females, which are still unknown on this part of the coast.

\section{Material and Methods}

\subsection{Field collections}

Crabs were collected monthly from January 1998 through December 1999 in Ubatumirim (UBM), Ubatuba (UBA), and Mar Virado (MV) bays on the southeastern Brazilian coast. Six transects were established in each bay, at 5, 10, 15, and $20 \mathrm{~m}$ (parallel to the beach line), as well as one transect in an area sheltered from wave action (7.5 $\mathrm{m}$ depth), and another in a more exposed area (10 $\mathrm{m}$ depth) (Figure 1). Environmental features of bays and transects were characterized by Bertini et al. (2010) and Lima et al. (2014). A shrimp fishing boat equipped with double-rig nets (mesh size $20 \mathrm{~mm}$ and $15 \mathrm{~mm}$ in the cod end) was used for sampling. Each transect was trawled over a 30-min period, covering an area of $18,000 \mathrm{~m}^{2}$.

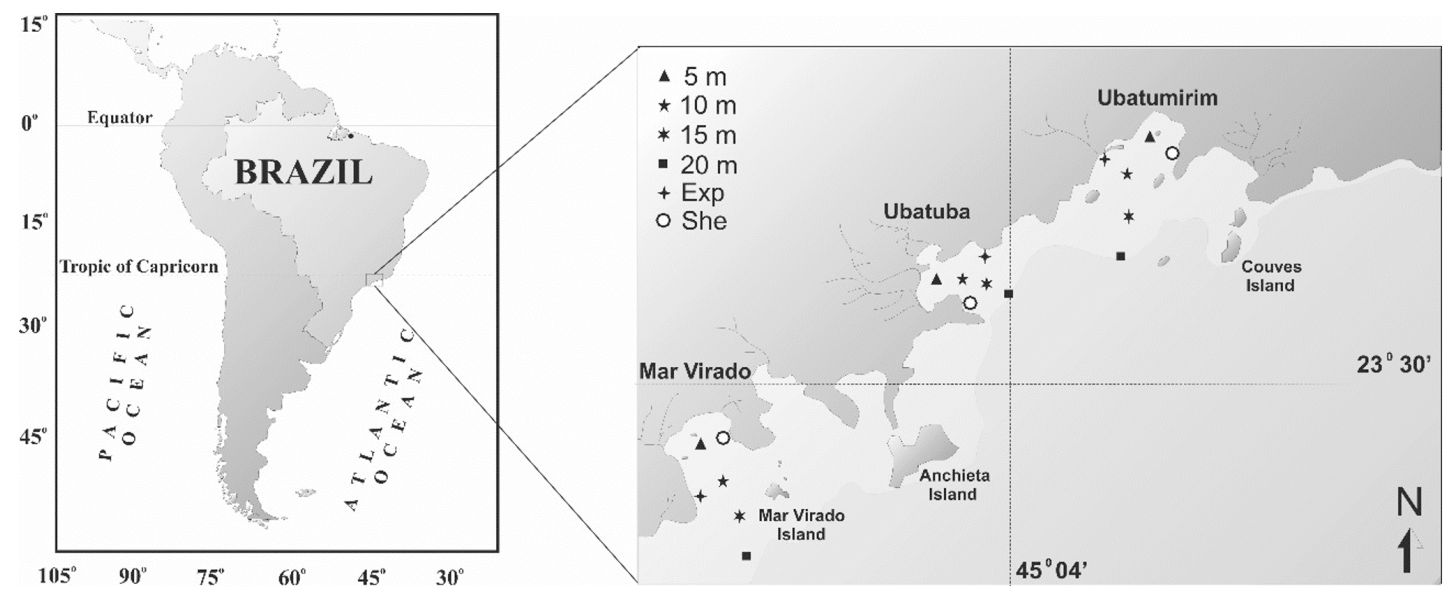

Figure 1. Map of the Ubatuba region on the northeastern coast of São Paulo State, southeastern Brazil, showing the sampling stations and depths. Exp = area exposed to wave action; She = area sheltered from wave action. 


\subsection{Environmental variables}

For each transect, the bottom temperature was recorded using a thermometer attached to a Nansen bottle. In each season, sediment samples were collected with a Van Veen grab, sampling a bottom area of $0.06 \mathrm{~m}^{2}$ in order to measure the organic-matter content (\%) and grain-size distribution of the sediments. All the procedures for sediment analysis followed Tucker (1988).

\subsection{Laboratory procedures and statistical analysis}

Specimens of $C$. danae were identified, counted and sexed. Shape, size, and color of gonads were analyzed. Juvenile individuals were used only to estimate sexual maturity. Three developmental stages were defined in adult females (AF) and adult males (AM) (rudimentary $=\mathrm{RU}$, developing $=\mathrm{ED}$ and developed $=\mathrm{DE}$ ), following the techniques proposed by Costa and Negreiros-Fransozo (1998). Females carrying eggs were termed ovigerous females (OF).

Prerequisites of normality and homoscedasticity were tested and accepted by the routines of Kolmogorov-Smirnov and Levene tests. The Chi-square was used to assess the significance of proportion comparison of each group among the bays. Data related to the abundance of each demographic group in each bay and seasons of two study periods were organized in a two factors contingence table to conduct a Correspondence Analysis (CA). During the CA the associations of both variables (demographic group, bays and seasons) were summarized by the frequency of each table cell, and then positioned in a geometric dimensional space, since the positions of each line and column were consistent with the associations of the table. Statistical significance of the eigen values and proportion was assessed using the chi-squared test with simulated p-value (based on 2000 randomizations) (Nenadic and Greenacre, 2007).

A one-way permutational analysis of variance (PerMANOVA) (Anderson, 2001) was used to assess the significance of the abundance of gonadal development stage of males and females among transects. A Principal Components Analysis (PCA) was used to identify the relationship among environmental variables and transects in each bay, as well as the relationship among the abundances of males and females in different gonadal development stages. Coordination scores were calculated using LC (linear combination), and the relative contribution of variables on each axis was determined from intra-set operations (McCune and Grace, 2002). The statistical significance of eigenvalues of the PCA axis was evaluated by randomization (Monte Carlo) tests, using 9999 randomized runs for each analysis. All multivariate analyses were performed using the software PC-ORD 6.0 (McCune and Mefford, 2011).

The reproductive period was determined by the presence of females with developed gonads and ovigerous females. A binomial test (Wilson and Hardy, 2002) was used to evaluate the proportion between males and females with reproductive potential (with developed gonads or breeding females) vs. males and females with developing gonads (rudimentary or in development) for each transect. To estimate sexual maturity for each bay, the relative frequency (\%) of adult size classes was plotted on graphs, which were fitted by the method of least squares to a sigmoid curve resulting from the logarithmic Equation 1:

$\mathrm{Y}=1 /\left[1+\mathrm{e}^{\mathrm{r}(\mathrm{CW}-\mathrm{CW} 50)}\right]$

where CW50 is the carapace width at which $50 \%$ of individuals attain sexual maturity, and $r$ is the curve slope (Vazzoler, 1996).

\section{Results}

A total of 3,041 individuals were collected during the study period, including 503 juveniles, which were used only to estimate sexual maturity. For the analyses 2,538 animals were used, 1,178 from UBM, 909 from UBA and 451 from MV. The abundance of AM and AF differed among the three bays (Chi-Square, $\mathrm{df}=2, \mathrm{p}<0.0001$ ), while $\mathrm{OF}$ was similar only between UBA and MV (Chi-Square, $\mathrm{df}=2$, $p>0.08$ ). Supplementing these results, the CA revealed that the most abundant demographic group was adult females (represented by the diameter of the circle), found in greater proportion in UBA. The greater proportion of ovigerous females and adult males occurred in UBM and MV, respectively (Figure 2a). In Ubatumirim, adult females were more abundant on autumn of second study period, and ovigerous females were more abundant on spring and summer of second period of study (Figure 2b). In Ubatuba and Mar Virado the greater abundance of ovigerous and adult females was observed on spring of the first period; the abundance of adult males followed adult females in most cases (Figure 2b).

The distributions of OF, AF and AM at different gonadal stages followed a pattern of preference for shallow and protected transects in the three bays (Table 1; Figure 3). Males and females in early gonadal development stages (MRU and FRU) showed no variance within groups, which did not allow well-founded comparisons of the transect factor. Females with rudimentary/developing gonads were found in fewer number than reproductive females, represented by less than $21 \%$ of total females; males with rudimentary/developing gonads were represented by $15 \%$ of total males.

The PCA indicated that specimens were strongly correlated among transects (Table 2; Figure 4A), since both sexes, at any gonadal development stage, were most abundant in sheltered areas, 5 and $10 \mathrm{~m}$ depth. In the three bays, the abundance of individuals was negatively related to 15 and $20 \mathrm{~m}$ depths and showed no strong correlations with exposed area. The PCA also showed a strong correlation among environmental variables and transects $(\%$ of variance $=58.76, p=12.00)$; however, transects at the same depth in the three bays did not necessarily have the same sedimentary features. In general, the proportions of silt + clay, the values of phi, and the organic-matter content (\%) increased from north to south in the bays. Within each 

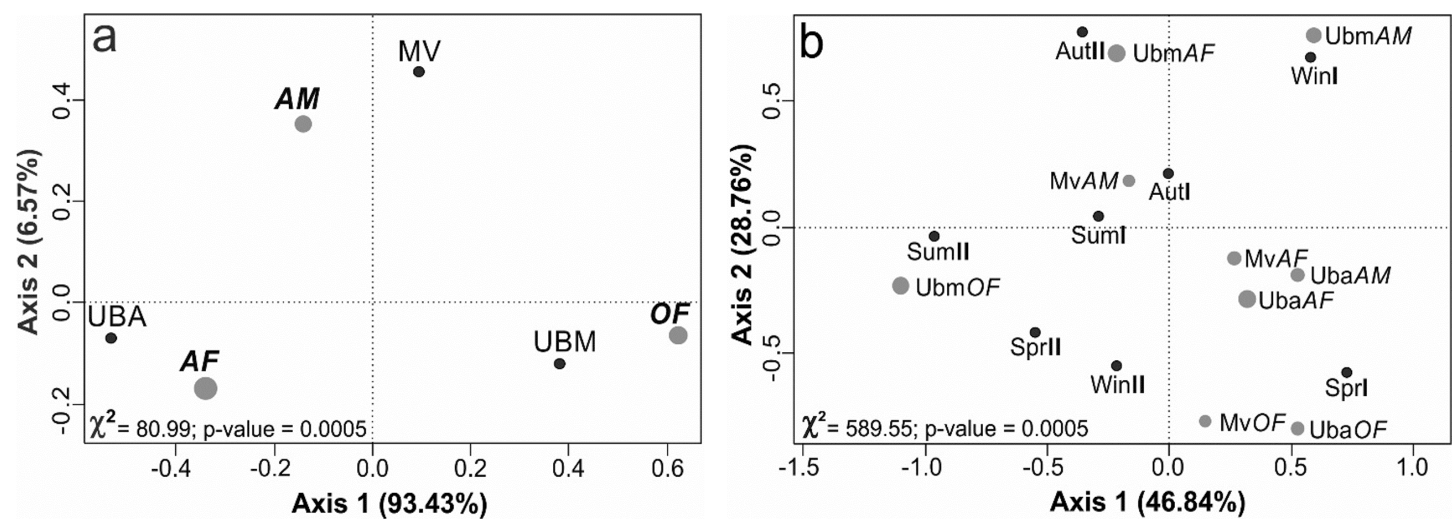

Figure 2. Correspondence analysis (CA) of (a) demographic groups of Callinectes danae and three bays in the subtropical region of Brazil; (b) demographic groups of bays and seasons in two study periods. $\mathrm{AM}=$ adult males; $\mathrm{AF}=$ adult females; $\mathrm{OF}=$ ovigerous females; $\mathrm{UBM}=$ Ubatumirim; UBA = Ubatuba; $\mathrm{MV}=$ Mar Virado; Sum = summer; Aut = autumn; win $=$ winter; $\mathrm{Spr}=$ spring.

Table 1. Distribution of males (M) and females (F) according to gonadal development stage in three bays in southeastern Brazil.

\begin{tabular}{|c|c|c|c|c|c|c|c|c|c|c|}
\hline & \multicolumn{6}{|c|}{ Transects } & \multirow{2}{*}{ Total } & \multirow{2}{*}{ Pseudo-F } & \multirow{2}{*}{$\mathbf{P}$} \\
\hline & & $5 \mathrm{~m}$ & $10 \mathrm{~m}$ & $15 \mathrm{~m}$ & $20 \mathrm{~m}$ & Exp & She & & & \\
\hline \multirow{7}{*}{ 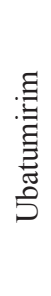 } & FRU & 14 & 5 & 0 & 0 & 1 & 46 & 66 & 8.2 & $0.00 *$ \\
\hline & FED & $12^{\mathrm{c}}$ & $11^{\mathrm{c}}$ & $1^{\mathrm{b}}$ & $0^{\mathrm{a}}$ & $6^{\mathrm{abc}}$ & $32^{\mathrm{d}}$ & 62 & 13.4 & 0.00 \\
\hline & FDE & $39^{\mathrm{cd}}$ & $69^{c}$ & $9^{b}$ & $1^{\mathrm{a}}$ & $21^{\mathrm{bd}}$ & $192^{\mathrm{e}}$ & 331 & 17.7 & 0.00 \\
\hline & $\mathrm{OF}$ & $96^{\mathrm{cd}}$ & $91^{\mathrm{c}}$ & $14^{\mathrm{b}}$ & $0^{\mathrm{a}}$ & $52^{\mathrm{c}}$ & $186^{\mathrm{d}}$ & 439 & 5.8 & 0.00 \\
\hline & MRU & 10 & 2 & 0 & 0 & 2 & 34 & 48 & 1.4 & $0.16^{*}$ \\
\hline & MED & 10 & 3 & 0 & 0 & 5 & 38 & 56 & 5.4 & $0.00^{*}$ \\
\hline & MDE & $43^{b}$ & $6^{\mathrm{a}}$ & $1^{\mathrm{a}}$ & $0^{\mathrm{a}}$ & $2^{a}$ & $124^{c}$ & 176 & 8.7 & 0.00 \\
\hline \multirow{7}{*}{$\begin{array}{l}\text { ڤే } \\
\text { 苂 } \\
\text { Dే }\end{array}$} & FRU & $60^{c}$ & $29^{\mathrm{bc}}$ & $1^{\mathrm{a}}$ & $0^{\mathrm{a}}$ & $4^{a b}$ & $7^{\mathrm{ab}}$ & 101 & 4.5 & 0.00 \\
\hline & FED & $89^{c}$ & $12^{\mathrm{b}}$ & $2^{\mathrm{ab}}$ & $0^{\mathrm{a}}$ & $6^{\mathrm{ab}}$ & $6^{\mathrm{ab}}$ & 115 & 9.3 & 0.00 \\
\hline & FDE & $188^{c}$ & $18^{\mathrm{b}}$ & $29^{b}$ & $0^{\mathrm{a}}$ & $20^{\mathrm{b}}$ & $5^{\mathrm{ab}}$ & 260 & 10.1 & 0.00 \\
\hline & $\mathrm{OF}$ & $144^{\mathrm{c}}$ & $7 b$ & $15^{\mathrm{b}}$ & $0^{\mathrm{a}}$ & $10^{\mathrm{ab}}$ & $6^{\mathrm{ab}}$ & 182 & 4.4 & 0.00 \\
\hline & MRU & 25 & 11 & 0 & 0 & 2 & 1 & 39 & 2.8 & $0.02 *$ \\
\hline & MED & 26 & 14 & 0 & 0 & 3 & 0 & 43 & 4.0 & $0.00^{*}$ \\
\hline & MDE & $128^{b}$ & $27^{\mathrm{a}}$ & $2^{\mathrm{a}}$ & $0^{\mathrm{a}}$ & $3^{a}$ & $9^{a}$ & 169 & 9.5 & 0.00 \\
\hline \multirow{7}{*}{ 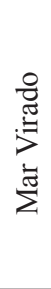 } & FRU & 5 & 5 & 0 & 0 & 1 & 1 & 12 & 1.5 & $0.17 *$ \\
\hline & FED & 6 & 3 & 7 & 0 & 0 & 8 & 24 & 1.2 & $0.30 *$ \\
\hline & FDE & $44^{c}$ & $13^{\mathrm{b}}$ & $34^{b c}$ & $1^{\mathrm{a}}$ & $5^{\mathrm{ab}}$ & $43^{c}$ & 140 & 4.9 & 0.00 \\
\hline & $\mathrm{OF}$ & $16^{\mathrm{b}}$ & $29^{b}$ & $37^{\mathrm{b}}$ & $0^{\mathrm{a}}$ & $5^{\mathrm{a}}$ & $52^{\mathrm{b}}$ & 139 & 2.9 & 0.02 \\
\hline & MRU & 2 & 4 & 0 & 0 & 2 & 5 & 13 & 1.7 & $0.15^{*}$ \\
\hline & MED & 3 & 1 & 0 & 0 & 1 & 16 & 21 & 10.4 & $0.00 *$ \\
\hline & MDE & 25 & 12 & 0 & 0 & 3 & 62 & 102 & 19.4 & $0.00 *$ \\
\hline
\end{tabular}

$*=$ no variance. Values with the same letters on the same line do not differ significantly. Refer to Table 2 for codes of demographic group and transects.

bay, the smallest proportions of silt + clay were observed at the $20 \mathrm{~m}$ depth, with an increase toward the nearshore transects (Table 3; Figure 4B). Transects farther from the coast had higher salinities (Table 3 ).

Reproduction was continuous, as indicated by the significant abundance of FDE and OF monthly, over the two years of study in the three bays (Figure 5). Likewise, MDE were also found throughout the study period (Figure 5). However, the proportion of specimens with reproductive potential (FDE + OF vs. MDE) was skewed toward females in all three areas $(\mathrm{UBM}=1: 0.2, \mathrm{p}=0.00 ; \mathrm{UBA}=1: 0.4$, $\mathrm{p}=0.00 ; \mathrm{MV}=1: 0.4, \mathrm{p}=0.00)$. The proportion between individuals without reproductive potential (FED + FRU vs. MED + MRU) showed a significant difference only 
(A) Ubatumirim

-OF $\because F D E$ GFED $\square F R U$

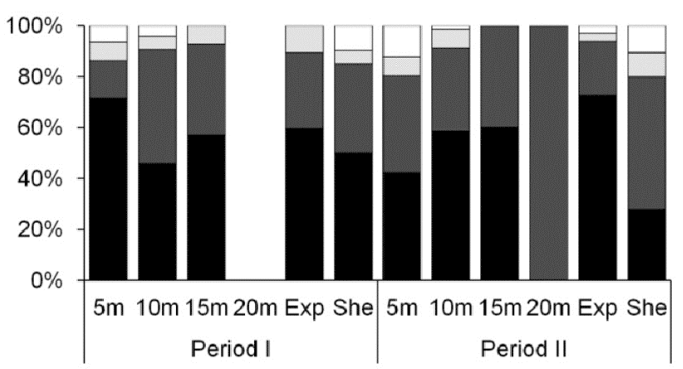

$\square$ MDE $\square$ MED $\square$ MRU

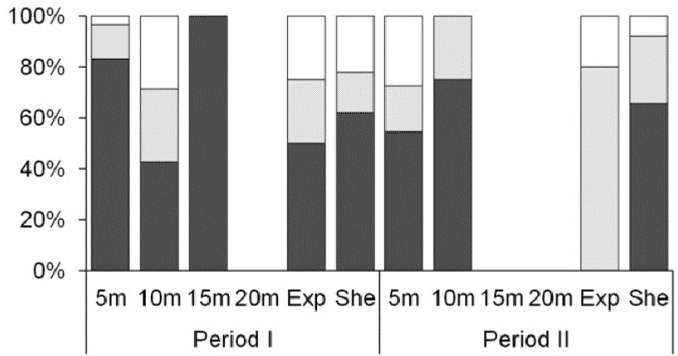

(B) Ubatuba
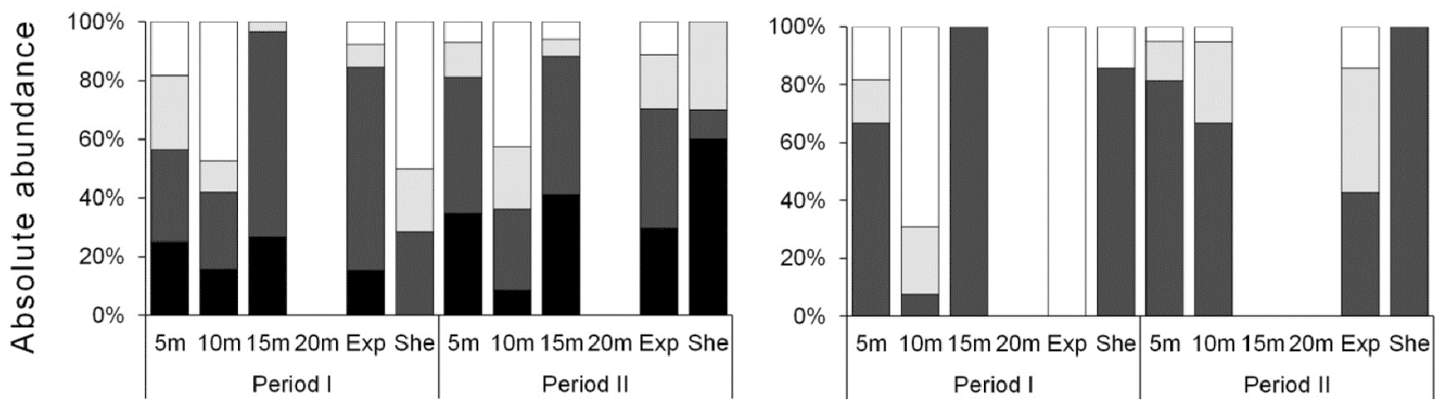

(C) Mar Virado
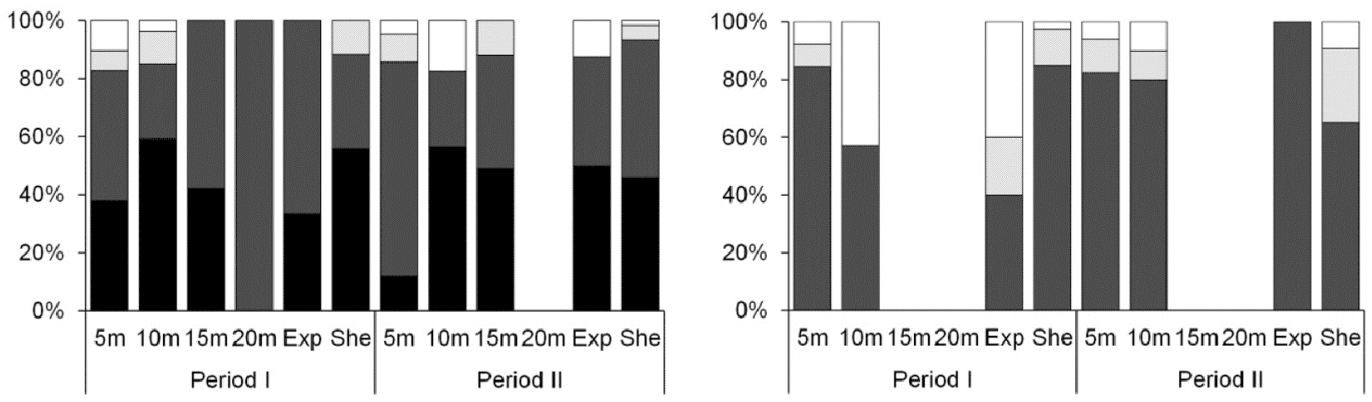

Figure 3. Relative frequency of female (F) and male (M) of Callinectes danae in different gonadal stages on six transects from three bays in southeastern Brazil. Refer to Table 2 for codes of each demographic group and transects.

in $\mathrm{UBA}(\mathrm{UBM}=1: 0.8, \mathrm{p}=0.12 ; \mathrm{UBA}=1: 0.4, \mathrm{p}=0.00$; $\mathrm{MV}=1: 0.9, \mathrm{p}=0.80)$.

The estimates of sexual maturity for males and females (CW50) were similar in the three bays, as were the sizes of the smallest male with developed gonads and the smallest ovigerous female (Table 4). In all estimates, males always reached maturity at larger sizes than females (Table 4).

\section{Discussion}

Adults of $C$. danae occur both inside and outside the estuary, although local characteristics, especially the sediment and salinity, determine their abundance. Comparison of neighbouring bays with different sediment characteristics, such as UBM, UBA and MV, can reveal how their environmental variations directly affect the abundance of reproductive male and female $C$. danae. However, such environmental changes do not seem to affect the reproductive patterns of the species, which showed continuous reproduction, with females reaching maturity at smaller sizes than males.

In the Ubatuba region, the environmental variations are related to the hydrodynamics regime (Bertini et al., 2010). During summer the inflow of South Atlantic Central Water enters along the bottom over the continental shelf, reaching coastal regions (Pires, 1992). The entrance of this cold water mass and the warming of surface water produce a thermocline, which in summer lies at depths below $15 \mathrm{~m}$, and contributes to the increase in primary productivity and consequent increase in food availability for heteroplanktonic larvae (Lopes et al., 2006). According Andrade et al. (2013a, b) this period favors the increase of reproductive females, in order to ensure the reproductive success of the species.

Differences in sediment grain size and organic-matter content among bays and transects also result from the local sediment dynamics, affected by the direction of ocean currents, wind and waves (Mahiques et al., 1998). MV Bay 
Table 2. Summary statistics of the axes generated by the Principal Components Analysis. Correlation between gonadal stages of Callinectes danae on six transects in Ubatumirim, Ubatuba and Mar Virado bays.

\begin{tabular}{|c|c|c|c|}
\hline Con & & Axis 1 & Axis 2 \\
\hline \multicolumn{4}{|c|}{ Gonadal stages } \\
\hline \multicolumn{4}{|c|}{ Females } \\
\hline Ovigerous fema & (OF) & -0.85 & 0.49 \\
\hline Developed gons & $(\mathrm{FDE})$ & -0.89 & 0.41 \\
\hline Developing gon & (FED) & -0.94 & 0.15 \\
\hline Rudimentary go & ls (FRU) & -0.89 & -0.31 \\
\hline \multicolumn{4}{|c|}{ Males } \\
\hline Developed gon: & $(\mathrm{MDE})$ & -0.93 & -0.21 \\
\hline Developing gon & (MED) & -0.92 & -0.19 \\
\hline Rudimentary go & is (MRU) & -0.94 & -0.29 \\
\hline Eigenvalue & & 5.79 & 0.69 \\
\hline$\%$ of Variance & & 82.79 & 9.89 \\
\hline \multicolumn{4}{|c|}{ Scores (transects of bays) } \\
\hline \multirow[t]{3}{*}{ Ubatumirim } & $5 \mathrm{~m}$ & -2.41 & -0.18 \\
\hline & $10 \mathrm{~m}$ & -1.06 & 1.11 \\
\hline & $15 \mathrm{~m}$ & 2.02 & 0.82 \\
\hline $20 \mathrm{~m}$ & & 3.41 & -0.72 \\
\hline Exposed & & -0.09 & 0.80 \\
\hline \multirow[t]{3}{*}{ Sheltered } & & -4.63 & -0.34 \\
\hline & $5 \mathrm{~m}$ & -4.75 & -0.21 \\
\hline & $10 \mathrm{~m}$ & -1.89 & -1.56 \\
\hline \multirow[t]{6}{*}{ Ubatuba } & $15 \mathrm{~m}$ & 1.30 & 1.02 \\
\hline & $20 \mathrm{~m}$ & 3.59 & -0.95 \\
\hline & Exposed & 0.07 & -0.01 \\
\hline & Sheltered & 0.71 & -0.51 \\
\hline & $5 \mathrm{~m}$ & -0.72 & 0.07 \\
\hline & $10 \mathrm{~m}$ & -0.16 & -0.14 \\
\hline \multirow[t]{4}{*}{ Mar Virado } & $15 \mathrm{~m}$ & 1.21 & 1.90 \\
\hline & $20 \mathrm{~m}$ & 3.41 & -0.72 \\
\hline & Exposed & 1.62 & -0.57 \\
\hline & Sheltered & -1.63 & 0.20 \\
\hline
\end{tabular}

is more influenced by the sedimentology of the continent than by ocean currents, since it is physically protected by the islands of San Sebastian, Vitória and Anchieta (Pires, 1992). Consequently, the predominant sediment in the area is composed of clay, often with high organicmatter content. Studies by Chacur and Negreiros-Fransozo (2001) found that $C$. danae was more abundant in areas with up to $10 \%$ organic matter in the sediment, which may explain the smaller number of individuals collected in MV. According to Andrade et al. (2013a, 2014a), the sediment in UBA is very similar to that in UBM; however, UBA is more impacted by sewage discharges, which increase the organic-matter content closer to the coast, perhaps explaining the lower abundance of crabs on the sheltered transect in this bay.

According to Costa and Negreiros-Fransozo (1998), environmental characteristics may influence the reproductive
Table 3. Summary statistics of the axes generated by the Principal Components Analysis. Correlation between environmental variables and transects of three bays.

\begin{tabular}{|c|c|c|c|}
\hline \multicolumn{2}{|c|}{ Contents } & Axis 1 & Axis 2 \\
\hline \multicolumn{4}{|c|}{ Environmental variables } \\
\hline \multicolumn{2}{|c|}{ Mean grain size $(\mathrm{PHI})$} & 0.95 & -0.04 \\
\hline \multicolumn{2}{|c|}{ Silt and clay $(\mathrm{S}+\mathrm{C})$} & 0.90 & -0.17 \\
\hline \multicolumn{2}{|c|}{ Bottom temperature (BT) } & 0.65 & -0.34 \\
\hline \multicolumn{2}{|c|}{ Organic matter (OM) } & 0.64 & -0.17 \\
\hline \multicolumn{2}{|c|}{ Coarse sand (CS) } & -0.93 & -0.32 \\
\hline \multicolumn{2}{|c|}{ Medium sand (MS) } & -0.93 & -0.14 \\
\hline \multicolumn{2}{|l|}{ Fine sand (FS) } & -0.80 & 0.32 \\
\hline \multicolumn{2}{|c|}{ Very coarse sand (VCS) } & -0.78 & -0.58 \\
\hline \multicolumn{2}{|c|}{ Salinity (SAL) } & -0.69 & 0.60 \\
\hline \multicolumn{2}{|c|}{ Biodetritus (BF) } & -0.66 & -0.62 \\
\hline \multicolumn{2}{|c|}{ Very fine sand (VFS) } & -0.13 & 0.69 \\
\hline \multicolumn{2}{|l|}{ Eigenvalue } & 6.46 & 1.97 \\
\hline \multicolumn{2}{|l|}{$\%$ of Variance } & 58.76 & 17.91 \\
\hline \multicolumn{4}{|c|}{ Scores (transects in bays) } \\
\hline \multirow{6}{*}{ Ubatumirim } & \multirow{2}{*}{$\begin{array}{l}5 \mathrm{~m} \\
10 \mathrm{~m}\end{array}$} & 1.44 & 1.07 \\
\hline & & -0.43 & 1.34 \\
\hline & $15 \mathrm{~m}$ & -2.10 & 1.50 \\
\hline & $20 \mathrm{~m}$ & -7.20 & -1.38 \\
\hline & Exposed & -0.75 & 0.98 \\
\hline & Sheltered & 0.04 & -0.65 \\
\hline \multirow{5}{*}{ Ubatuba } & \multirow{2}{*}{$\begin{array}{c}5 \mathrm{~m} \\
10 \mathrm{~m}\end{array}$} & 2.06 & -1.47 \\
\hline & & 1.04 & -0.26 \\
\hline & $15 \mathrm{~m}$ & 0.00 & 2.17 \\
\hline & $20 \mathrm{~m}$ & -2.93 & 1.67 \\
\hline & Exposed & 1.94 & 1.21 \\
\hline \multirow{7}{*}{ Mar Virado } & Sheltered & -2.39 & -2.72 \\
\hline & $5 \mathrm{~m}$ & 3.42 & -0.69 \\
\hline & $10 \mathrm{~m}$ & 3.17 & -0.64 \\
\hline & $15 \mathrm{~m}$ & 1.56 & 0.42 \\
\hline & $20 \mathrm{~m}$ & -2.04 & 0.27 \\
\hline & Exposed & 2.02 & -0.13 \\
\hline & Sheltered & 1.14 & -2.70 \\
\hline
\end{tabular}

cycle of a species not only by individual factors, but also by combinations of factors such as competition for food, predation, and behavior. Andrade et al. (2014a) extrapolated this statement in determining the differential distribution of Callinectes ornatus Ordway, 1863 in different states of reproductive potential. Based on the same principles, Andrade et al. (2014b) found differential occupation of the habitat by different demographic groups of Eriphia gonagra (Fabricius, 1781). The results of the present study revealed that areas farther the coast were not densely occupied by males and females with rudimentary or developing gonads, which were found in fewer numbers; however, reproductive females were found at depths up to $15 \mathrm{~m}$ (see Table 1 and Figure 3). According to Barreto et al. (2006), females of C. danae with developed gonads are usually found in deeper waters. Barreto et al. (2006) also suggested that this may be associated with the higher salinity of areas 


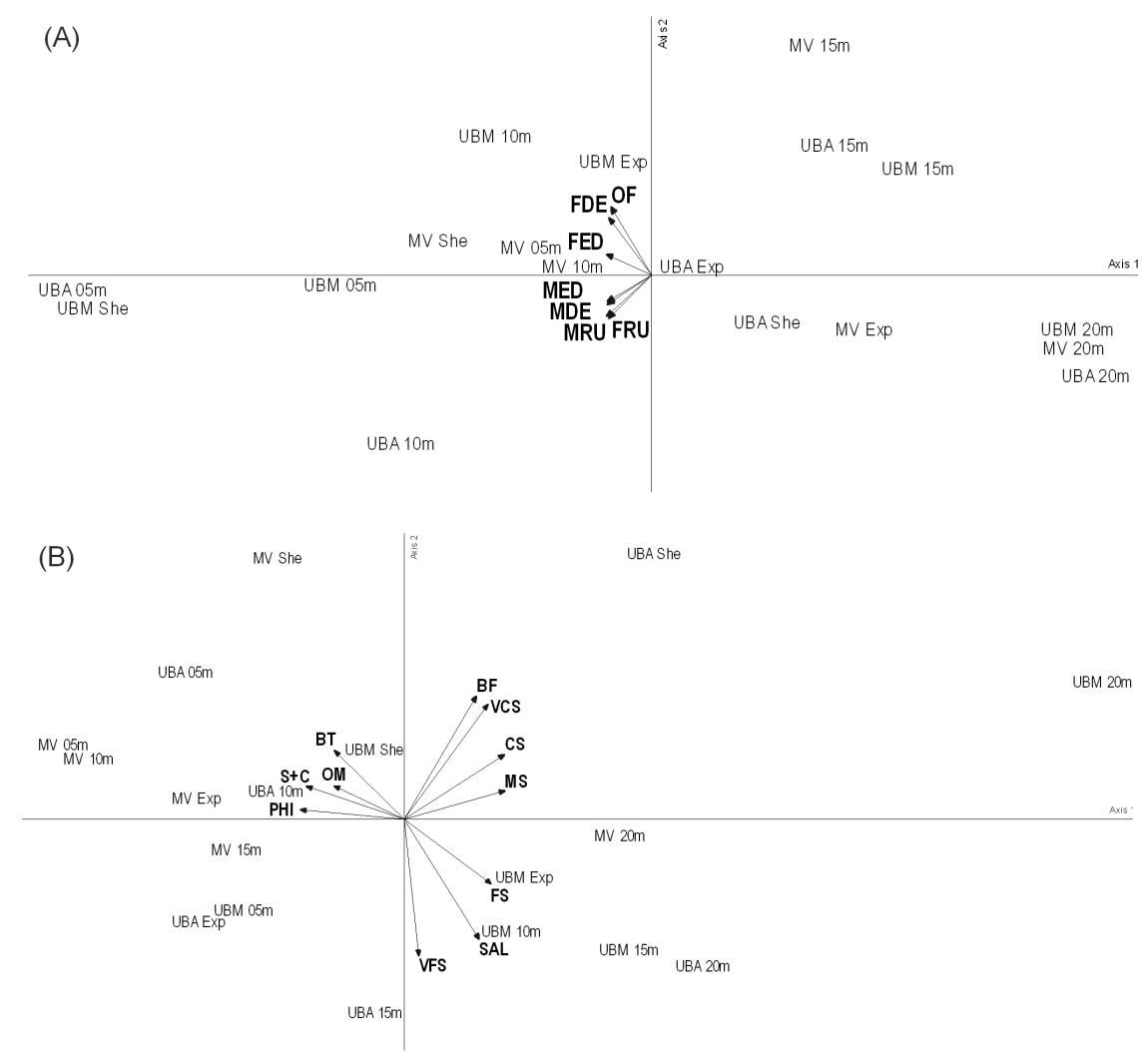

Figure 4. PCA biplot showing the degree of correlation among (A) males and females of Callinectes danae in different gonadal stages and transects in three bays, and (B) environmental factors and transects in three bays. Refer to Table 2 for codes of each demographic group and transects.

farther offshore, suitable for the development of eggs during incubation (see Hines et al., 2008). Similarly, the greater abundance of individuals with developing gonads (ED) in areas closer to the coast can be explained by the proximity to estuaries, ideal areas for the development of young (Sforza et al., 2010), since they provide more food and refuge (Burone et al., 2003). Thus, the small number of adults with rudimentary/developing gonads can be explained by a migratory process, which occurs from estuary to the bays, according the gonadal development for reproductive activity.

Reproductive migration from estuarine areas to bays is widely reported for members of the genus Callinectes Stimpson, 1860. Aguilar et al. (2005) studied the migratory behavior of female Callinectes sapidus Rathbun, 1896 in Chesapeake Bay, and observed that newly mated females remained in estuaries during the summer, migrated to the bay in early autumn, and spawned in areas with higher salinity. Andrade et al. (2014a) found similar migratory behavior in female $C$. ornatus. Although it is not an estuary-dependent species, Andrade et al. (2014a) reported that females migrated to the deeper regions during gonadal development. Sforza et al. (2010), studying the distribution of $C$. danae in an estuary, found adult and ovigerous females only in its mouth, with large numbers of juvenile males throughout the sampling area. These reports indicate that migration to more distant areas of the estuary ensures reproductive success, and also facilitates larval dispersal (Hines et al., 2008).

Similarly to females, a few males with reproductive potential may also leave the estuary to find females who are beginning to migrate. The ratio between reproductive females and males (FDE + OF vs. MDE) reveals this clearly. Reproductive females were significantly more abundant than males in the bays, probably because they tend to remain in the estuary. The ratio of non-reproductive females and males (FRU + FED vs. MRU + MED) did not differ significantly. According to Sastry (1983) and Bauer and Lin (1994), migratory behavior can be altered by environmental changes that influence procreation, and such changes can be modulated by several factors, including temperature, sediment type and salinity. Patterns of continuous reproduction indicate that individuals can reproduce asynchronously; in other words, while some individuals are growing, others are maturing and reproducing. This type of reproduction is common in Portunoidea of tropical and subtropical regions (Amaro Pinheiro and Fransozo, 1998; Costa and Negreiros-Fransozo, 1998; Andrade et al., 2014a). 


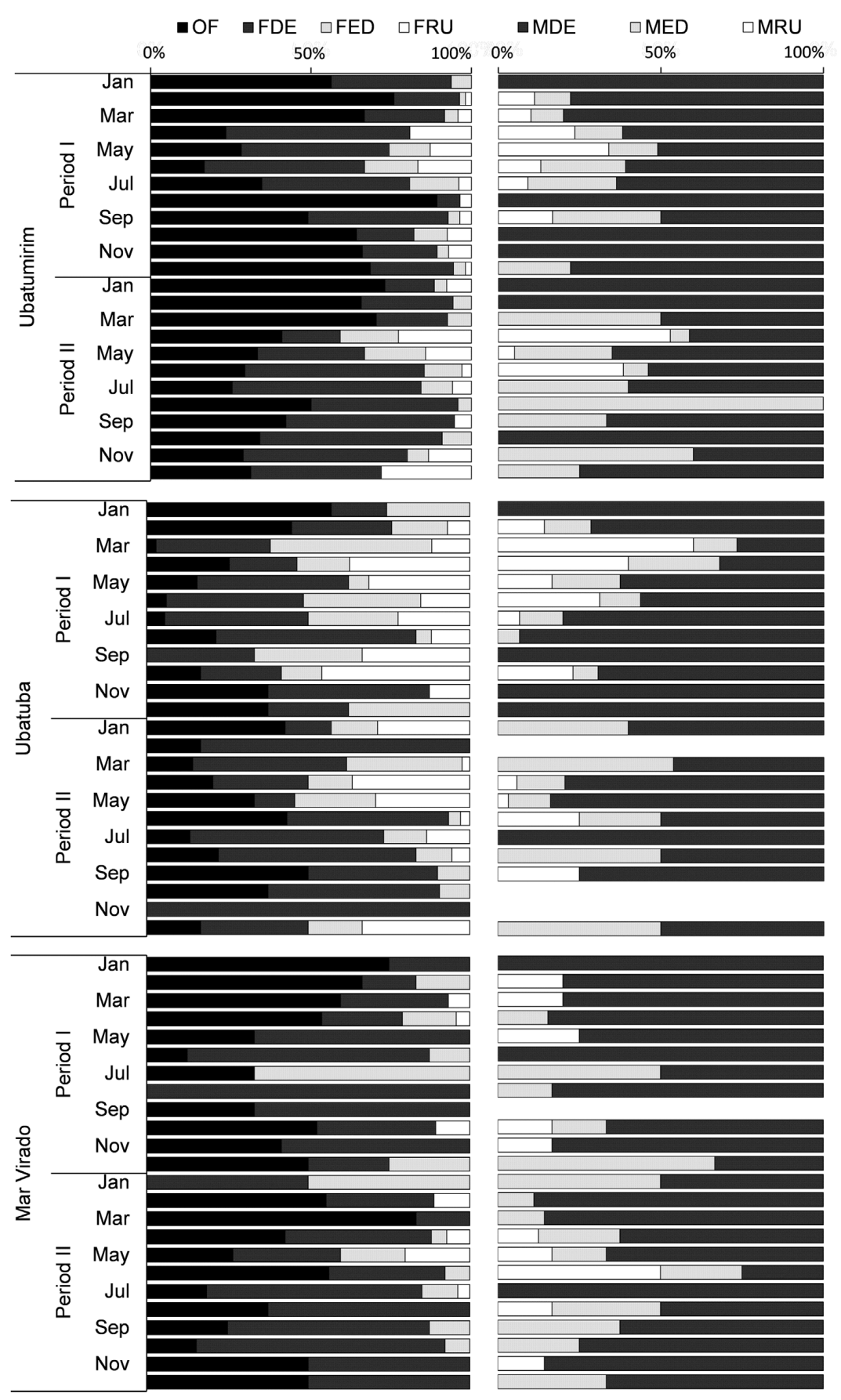

Figure 5. Monthly variation in the proportion of adult females $(F)$ and adult males $(M)$ in six transects in three bays on the southern Brazilian coast. Refer to Table 2 for codes of each demographic group.

Table 4. Sexual maturity for males and females of Callinectes danae from three bays in southeastern Brazil.

\begin{tabular}{lcccc}
\hline \multirow{2}{*}{ Bay } & \multicolumn{2}{c}{ CW50 (mm) } & \multicolumn{2}{c}{ Smallest size } \\
\cline { 2 - 5 } & Males & Females & MDE & OF \\
\hline Ubatumirim & 60.2 & 55.1 & 61.4 & 52.3 \\
Ubatuba & 58.0 & 55.4 & 63.0 & 53.8 \\
Mar Virado & 58.4 & 54.6 & 61.8 & 54.6 \\
\hline \multicolumn{2}{l}{ CW50 = carapace width at which $50 \%$ of individuals are mature. MDE $=$ males with developed gonads. OF = ovigerous females. }
\end{tabular}


The percentage of ovigerous females observed during the year is the most common index used to estimate the reproductive periodicity of the species; however, the frequency of gonadal activity is also informative, since a high percentage of females with developed gonads throughout the year indicates their good nutritional status. The presence of reproductive females and males throughout the year may indicate that the environment provides the nutrients necessary for their development (Wenner et al., 1974). The present study showed a significant monthly frequency of males and females with developed gonads over the two years of study, indicating that these bays seem to meet the nutritional needs of the species. Other studies have also found a continuous reproductive pattern, using the same methodology (Branco and Masunari, 2000; Keunecke et al., 2012; Sant'Anna et al., 2012; Marochi et al., 2013).

The feeding conditions in an area can also govern other reproductive characteristics of a species, such as the age and size at which it reaches sexual maturity. However, this maturity is also governed by the reproductive behavior of the species. The present results for sexual maturity showed that male $C$. danae reach maturity at larger sizes than females. This difference, according to Mantelatto and Fransozo (1996), is a reproductive adaptation, since this dimorphism confers greater protection to fertilized females, after copulation, with the completion of the post-copulatory embrace. The maturation sizes of males and females in these bays are similar to those of individuals from Paraná (less than $700 \mathrm{~km}$ to the south), studied by Baptista-Metri et al. (2005). However, females studied by Barreto et al. (2006), collected in Pernambuco (over 2,500 km to the north) matured at $63.5 \mathrm{~mm} \mathrm{CW}$, almost $8 \mathrm{~mm} \mathrm{CW}$ larger than the smallest mature specimen found here. According to Hartnoll (1982), species in areas with optimal conditions for their development can reach sexual maturity at smaller sizes, and a difference in environmental conditions may account for the smaller size at maturity estimated in the present study. As described by Castro-Filho et al. (1987) and Vega-Pérez (1993), the southeastern state of São Paulo lies in a nutrient-rich zone of faunal transition between tropical and subtropical regions.

Comparisons with other studies conducted in the south (Branco and Masunari, 2000; Marochi et al., 2013) could not be performed because the authors included the lateral spines in the carapace measurement. Here, the carapace width was measured from the base of the lateral spines, since these spikes may be broken or suffer wear and tear over time. Likewise, the study by Araujo et al. (2012) was not taken into consideration, since they evaluated individuals with rudimentary gonads as juveniles.

Accurate estimation of the size at which gonadal maturation begins is crucial for conservation of the species because it provides important information for the management of stocks, which is based on a minimum allowable catch size (Andrade et al., 2013b). In the present study, even with collections outside the estuary, $23.6 \%$ of the individuals caught were smaller than the size at first maturation. This percentage indicates that the fishing gear used in shrimp fisheries can potentially affect the population balance, and populations under intense fishing pressure may have their asymptotic size reduced, and consequently the size at first maturity may also decrease. This may represent an additional cost for the species, since smaller sizes at maturity affect fecundity, reflecting the decrease in reproductive potential (Keunecke et al., 2012). Information such as this is essential for collecting management data and for conservation of estuarine faunas, particularly on the southeastern coast of Brazil.

Investigations on the reproductive biology of $C$. danae collected outside the estuary provided more information about the habitat preferences of individuals with reproductive potential, and consequently more-consistent results with respect to the reproduction of the species. The collection of specimens of $C$. danae exclusively from the estuary may cause failures in estimating sexual maturity, since overestimated values can lead to erroneous conclusions about reproductive adjustments.

The results of the present study indicated that the pattern of spatio-temporal distribution of adults $C$. danae was similar in three bays on the northern coast of São Paulo, although the highest abundance was found in Ubatumirim Bay. Reproductive males and females were found in greater abundance than swimming crabs with rudimentary/developing gonads, indicating that such individuals may be within the estuary. This result emphasizes a migratory process to the bays in order to ensure success in reproductive activities. In this way, Ubatumirim and Ubatuba Bays require special attention regarding their ecological equilibrium, since potential reproductive females are more abundant in these areas, mainly on spring and summer.

\section{Acknowledgments}

We are grateful to the Fundação de Amparo à Pesquisa do Estado de São Paulo (FAPESP) for providing financial support (\#97/12106-8; \#97/12108-6; \#97/12107-0). We are also thankful to the NEBECC coworkers for their help during the fieldwork, and to Dr. Janet W. Reid for her valuable help with the English language and editing. All sampling in this study has been conducted in compliance with applicable state and federal laws.

\section{References}

AGUILAR, R., HINES, AH., WOLCOTT, TG., WOLCOTT, DL., KRAMER, MA., and LIPCIUS, RN., 2005. The timing and route of movement and migration of post-copulatory female blue crabs, Callinectes sapidus Rathbun, from the upper Chesapeake Bay. Journal of Experimental Marine Biology and Ecology, vol. 319, no. 1, p. 117-128. http:// doi:10.1016/j.jembe.2004.08.030.

ALMEIDA, AA., FRANSOZO, V., MONTEIRO TEIXEIRA, GM., FURLAN, M., HIROKI, KAN. and FRANSOZO, A., 2011. Population structure period of white belly prawn Nematopalaemon schmitti (Holthuis, 1850) (Decapoda: Palaemonidae) on the southern coast of Brazil. Invertebrate Reproduction \& Development, vol. 55, p. 30-39. http://dx.doi.org/10.1080/07924259.2010.548641. 
AMARO PINHEIRO, MAA. and FRANSOZO, A., 1998. Sexual maturity of the speckled swimming crab Arenaeus cribrarius (Lamarck, 1818) (Decapoda, Brachyura, Portunidae), in the Ubatuba littoral, São Paulo state, Brazil. Crustaceana, vol. 71, no. 4, p. 434-452. http://dx.doi.org/10.1163/156854098X00536.

ANDERSON, MJ., 2001. A new method for non-parametric multivariate analysis of variance. Austral Ecology, vol. 26, no. 1, p. 32-46.

ANDRADE, LS., BERTINI, G., FRANSOZO, F., TEIXEIRA, GM., BARROS-ALVES, SP. and FRANSOZO, A., 2014a. Differential occupation of habitat as a reproductive strategy of the blue crab Callinectes ornatus Ordway, 1968 (Crustacea: Decapoda). Marine Biodiversity, vol. 44, no. 1, p. 27-36. http:// dx.doi.org/10.1007/s12526-013-0179-y.

ANDRADE, LS., FRANSOZO, V., BERTINI, G., NEGREIROSFRANSOZO, ML. and LÓPEZ-GRECO, LS., 2013b. Reproductive plasticity in the speckled crab Arenaeus cribrarius (Decapoda, Brachyura, Portunidae) associated with a population decline. Journal of Coastal Research. http://dx.doi.org/10.2112/ JCOASTRES-D-13-00066.1.

ANDRADE, LS., FRANSOZO, V., COBO, VJ., CASTILHO, AL., BERTINI, G. and FRANSOZO, A., 2013a. Ontogenetic distribution of Callinectes ornatus (Decapoda, Portunoidea) in southeastern Brazil. Ciencias Marinas, vol. 39, no. 4, p. 371-385. http://dx.doi.org/10.7773/cm.v39i4.2280.

ANDRADE, LS., GOÉS, JM., FRANSOZO, V., ALVES, DFR., TEIXEIRA, GM. and FRANSOZO, A., 2014b. Differential habitat use by demographic groups of the redfinger rubble crab Eriphia gonagra (Fabricius, 1781). Brazilian Journal of Biology, vol. 74, no. 3, p. 597-606. http://dx.doi.org/10.1590/bjb.2014.0090. PMid:25296208.

ARAÚJO, MS., NEGROMONTE, AO., BARRETO, AV. and CASTIGLIONI, DS., 2012. Sexual maturity of the swimming crab Callinectes danae (Crustacea: Portunidae) at the Santa Cruz Channel, a tropical coastal environment. Journal of the Marine Biological Association of the United Kingdom, vol. 92, no. 2, p. 287-293. http://dx.doi.org/10.1017/S0025315411001135.

BAPTISTA-METRI, C., PINHEIRO, MAA., BLANKENSTEYN, A. and BORZONE, CA., 2005. Biologia populacional e reprodutiva de Callinectes danae Smith (Crustacea, Portunidae), no Balneário de Shangri - lá, Pontal do Paraná, Paraná, Brasil. Revista Brasileira de Zoologia, vol. 22, no. 2, p. 446-466. http://dx.doi.org/10.1590/ S0101-81752005000200022.

BARRETO, ADV., BATISTA-LEITE, LDMA. and AGUIAR, MC., 2006. Maturidade sexual das fêmeas de Callinectes danae (Crustacea, Decapoda, Portunidae) nos estuários dos rios Botafogo e Carrapicho, Itamaracá, PE, Brasil. Iheringia. Série Zoologia, vol. 96 , no. 2, p. 141-146.

BAUER, RT. and LIN, J., 1994. Temporal patterns of reproduction and recruitment in populations of the penaeid shrimps Trachypenaeus similis (Smith) and T. constrictus (Stimpson) (Crustacea: Decapoda) form the north-central Gulf of Mexico. Journal of Experimental Marine Biology and Ecology, vol. 182, no. 2, p. 205-222. http:// dx.doi.org/10.1016/0022-0981(94)90052-3.

BERTINI, G., FRANSOZO, A. and NEGREIROS-FRANSOZO, ML., 2010. Brachyuran soft-bottom assemblage from marine shallow waters in the southeastern Brazilian littoral. Marine Biodiversity, vol. 40, no. 4, p. 277-291. http://dx.doi.org/10.1007/ s12526-010-0049-9.
BRANCO, JO. and MASUNARI, S., 2000. Reproductive ecology of the blue crab, Callinectes danae Smith, 1869 in the Conceição Lagoon system, Santa Catarina Isle, Brazil. Brazilian Journal of Biology, vol. 60, no. 1, p. 17-27. http://dx.doi.org/10.1590/ S0034-71082000000100004. PMid:10838920.

BURONE, L., MUNIZ, P., PIRES-VANIN, MAS. and RODRIGUES, M., 2003. Spatial distribution of organic matter in the surface sediments of Ubatuba Bay (Southeastern - Brazil). Anais da Academia Brasileira de Ciencias, vol. 75, no. 1, p. 77-90. http:// dx.doi.org/10.1590/S0001-37652003000100009.

CASTRO-FILHO, BM., MIRANDA, LB., and MIYAO, SY., 1987. Condições hidrográficas na Plataforma Continental ao largo de Ubatuba: variações sazonais e em média escala. Boletim do Instituto Oceanográfico de São Paulo, vol. 35, no. 2, p. 135-151.

CHACUR, MM. and NEGREIROS-FRANSOZO, ML., 2001. Spatial and seasonal distributions of Callinectes danae (Decapoda, Portunidae) in Ubatuba Bay, São Paulo, Brazil. Journal of Crustacean Biology, vol. 21, no. 2, p. 414-425. http://dx.doi. org/10.1163/20021975-99990142.

COSTA, TM. and NEGREIROS-FRANSOZO, ML., 1998. The reproductive cycle of Callinectes danae Smith, 1869 (Decapoda, Portunidae) in the Ubatuba region, Brazil. Crustaceana, vol. 71, no. 6, p. 615-627. http://dx.doi.org/10.1163/156854098X00617.

DIEGUES, AC., 1999. Human populations and coastal wetlands: conservation and management in Brazil. Ocean \& Coastal Management, vol. 42, no. 2, p. 187-210. http:// 10.1016/S09645691(98)00053-2.

HARTNOLL, RG., 1982. Growth. In BLISS, DE. (Ed.). The biology of Crustacea: embryology, morphology and genetics. New York: Academic Press. p. 111-196.

HINES, AH., JOHNSON, EG., YOUNG, AC., AGUILAR, R., KRAMER, MA., GOODISON, M., ZMORA, O. and ZOHAR, Y., 2008. Release strategies for estuarine species with complex migratory life cycles: stock enhancement of Chesapeake blue crabs. Reviews in Fisheries Science, vol. 16, no. 1-3, p. 175-185. http://dx.doi.org/10.1080/10641260701678090.

KEUNECKE, KA., D'INCAO, F., VERANI, JR. and VIANNA, M., 2012. Reproductive strategies of two sympatric swimming crabs Callinectes danae and Callinectes ornatus (Crustacea: Portunidae) in an estuarine system, south-eastern Brazil. Journal of the Marine Biological Association of the United Kingdom, vol. 92, no. 2, p. 343-347. http://doi:10.1017/S0025315411000397.

KEUNECKE, KA., SILVA, DR., VIANNA, M., VERANI, JR. and D'INCAO, F., 2009. Ovarian development stages of Callinectes danae and Callinectes ornatus (Brachyura, Portunidae). Crustaceana, vol. 82, no. 6, p. 753-761. http://dx.doi. org/10.1163/156854009X423175.

LIMA, PA., FRANSOZO, V., ANDRADE, LS., ALMEIDA, AC., FURLAN, M. and FRANSOZO, A., 2014. Distribution and population structure of the flecked box crab Hepatus pudibundus (Decapoda, Brachyura) in the western South Atlantic. Marine Biology Research, vol. 10, no. 6, p. 589-600. http://dx.doi.org/1 0.1080/17451000.2013.841940.

LOPES, RM., KATSURAGAWA, M., DIAS, JF., MONTÚ, MA., MUELBERT, JH., GORRI, C. and BRANDINI, PF., 2006. Zooplankton and ichthyoplankton distribution on the southern Brazilian shelf: an overview. Scientia Marina, vol. 70, no. 2, p. $189-202$. 
MAHIQUES, MM., TESSLER, MG. and FURTADO, VV., 1998. Characterization of energy gradient in enclosed bays of Ubatuba region, south-eastern Brazil. Estuarine, Coastal and Shelf Science, vol. 47, no. 4, p. 431-446. http://dx.doi.org/10.1006/ecss.1998.0368.

MANTELATTO, FLM. and FRANSOZO, A., 1996. Size at maturity in Callinectes ornatus (Brachyura, Portunidae) from the Ubatuba Region (SP), Brazil. Nauplius, vol. 4, p. 29-38.

MAROCHI, MZ., MORETO, TF., LACERDA, MB., TREVISAN, A. and MASUNARI, S., 2013. Sexual maturity and reproductive period of the swimming blue crab Callinectes danae Smith, 1869 (Brachyura: Portunidae) from Guaratuba Bay, Paraná State, southern Brazil. Nauplius, vol. 21, no. 1, p. 43-52. http://dx.doi. org/10.1590/S0104-64972013000100006.

MCCUNE, B. and GRACE, JB., 2002. Analysis of ecological communities. Gleneden Beach, Oregon: MJM Software Design.

MCCUNE, B. and MEFFORD, MJ., 2011. PC-ORD. Multivariate analysis of ecological data. Version 6.0. Gleneden Beach, Oregon: MJM Software Design.

NENADIC, O. and GREENACRE, M., 2007. Correspondence analysis in R, with two- and three dimensional graphics: The ca package. Journal of Statistical Software, vol. 20, no. 3, p. 1-13.

PIRES, AMS., 1992. Structure and dynamics of benthic megafauna on the continental shelf offshore of Ubatuba, southeastern Brazil. Marine Ecology Progress Series, vol. 86, p. 63-76. http://dx.doi. org/10.3354/meps086063.

SANT'ANNA, BS., TURRA, A. and ZARA, FJ., 2012. Reproductive migration and population dynamics of the blue crab Callinectes danae in an estuary in southeastern Brazil. Marine Biology Research, vol. 8, no. 4, p. 354-362. http://dx.doi.org/10.1080/1 7451000.2011 .637563 .

SASTRY, AN., 1983. Ecological aspects of reproduction. In BLISS, DE. (Ed.). The biology of Crustacea: environmental adaptations. New York: Academic Press. p. 179-270.

SFORZA, R., NALESSO, RC. and JOYEUX, JC., 2010. Distribution and population structure of Callinectes danae (Decapoda: Portunidae) in a tropical Brazilian estuary. Journal of Crustacean Biology, vol. 30, no. 4, p. 597-606. http://dx.doi. org/10.1651/09-3223.1.

TUCKER, M., 1988. Techniques in sedimentology. Cambridge: Blackwell Scientific Publications.

VAZZOLER, AEAM., 1996. Biologia da reprodução de peixes teleósteos: teorias e práticas. Maringá: Eduem.

VEGA-PÉREZ, LA., 1993. Estudo do zooplâncton da região de Ubatuba, Estado de São Paulo. Publicação Especial do Instituto Oceanográfico, vol. 10, p. 65-84.

WENNER, AM., FUSARO, C. and OATEN, A., 1974. Size at onset of sexual maturity and growth rate in crustacean populations. Canadian Journal of Zoology, vol. 52, no. 9, p. 1095-1106. http:// dx.doi.org/10.1139/z74-147. PMid:4417012.

WILSON, K. and HARDY, ICW., 2002. Statistical analysis of sex ratios: an introduction. In HARDY, ICW. (Ed.). Sex Ratios: Concepts and Research Methods. Cambridge: Cambridge University Press. p. 48-92. http://dx.doi.org/10.1017/CBO9780511542053.004. 